\section{Viability of seedling image analysis (Vigor-S) to determine the physiological potential of melon seeds}

\author{
Moadir de Sousa Leite ${ }^{1 *}$ (D), Salvador Barros Torres ${ }^{1}$ (D) Francisco Guilhien

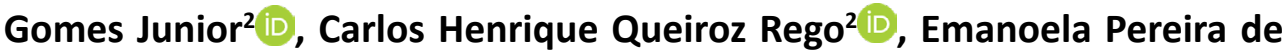 \\ Paiva $^{1}\left[\right.$ D, Tiago de Sousa Leite ${ }^{1}$ ii
}

\begin{abstract}
Melon is a vegetable crop of food and nutritional importance whose cultivation is growing worldwide. In this sense, investments in technologies are necessary, especially regarding the quality of seeds used in the establishment of new areas. This study aimed to verify the effectiveness of the Automated Seed Vigor Analysis System (Vigor-S) in the evaluation of the physiological potential of melon seeds. Eight seed lots (four lots of the hybrid Supreme and four of the hybrid Premier) were used. The physiological potential of the seeds was evaluated through tests indicated for analyzing the quality of melon seeds associated with the image analysis by using the software Vigor-S, which included the analysis of seedlings from the germination test and accelerated aging in saturated $\mathrm{NaCl}$ solution. The experiment was conducted in a completely randomized design, with five replications. The results indicated the effectiveness of Vigor-S, especially when it was used associated with the accelerated aging test in saturated $\mathrm{NaCl}$ solution, with results similar to those obtained in traditional vigor tests. Thus, the Automated Seed Vigor Analysis System (Vigor-S) was effective in evaluating the physiological potential of melon seeds.
\end{abstract}

Index terms: image analysis, Cucumis melo L., Cucurbitaceae.

\section{Viabilidade da análise de imagens de plântulas (Vigor-S) na} determinação do potencial fisiológico de sementes de melão

RESUMO: O melão é uma olerícola de importância alimentícia e nutricional, cujo cultivo vem crescendo mundialmente. Em função disso, investimentos em tecnologias serão necessários, especialmente no tocante à qualidade de sementes utilizadas no estabelecimento de novas áreas. Objetivou-se verificar a eficiência do Sistema de Análise Automatizada do Vigor de Sementes (Vigor-S) na avaliação do potencial fisiológico de sementes de melão. Utilizou-se oito lotes de sementes, quatro do híbrido Supreme e quatro do Premier. O potencial fisiológico das sementes foi avaliado por meio de testes já indicados para a análise da qualidade de sementes da cultura do melão, juntamente a análise de imagens pelo software Vigor-S, que englobou as análises de plântulas dos testes de germinação e envelhecimento acelerado em solução saturada de $\mathrm{NaCl}$. O experimento foi conduzido em delineamento inteiramente casualizado, com cinco repetições. Os resultados indicaram eficiência do Vigor-S, sobretudo quando este foi utilizado juntamente ao teste de envelhecimento acelerado em solução saturada de $\mathrm{NaCl}$, com resultados semelhantes aos obtidos nos testes de vigor tradicionais. Dessa forma, concluiu-se que a Análise Automatizada do Vigor de Sementes (Vigor-S) se mostrou eficiente na avaliação do potencial fisiológico de sementes de melão.

Termos para indexação: análise de imagens, Cucumis melo L., Cucurbitaceae.
Journal of Seed Science, v.42, e202042043, 2020

http://dx.doi.org/10.1590/ 2317-1545v42237826

\section{*Corresponding author} E-mail: moadir@outlook.com

Received: 5/9/2020. Accepted: 11/5/2020.

${ }^{1}$ Departamento de Ciências Agronômicas e Florestais, Universidade Federal Rural do Semi-Árido, 59625-900 - Mossoró, RN, Brasil.

\footnotetext{
2Departamento de Agricultura, Universidade de São Paulo, Escola Superior de Agricultura Luiz de Queiroz, 13418-900 - Piracicaba, SP, Brasil.
} 


\section{INTRODUCTION}

Melon (Cucumis melo L.) is a vegetable crop of food and nutritional importance whose cultivation is growing worldwide (Medeiros et al., 2015). In Brazil, this fruit vegetable stands out in the semi-arid of the Northeast region (Barros et al., 2019; Deus et al., 2015), and most of its production is exported to the European market (Bessa et al., 2018).

Melon planting is carried out predominantly using seedlings (indirect sowing). Thus, the use of seeds with high physiological potential is essential to obtain high-quality seedlings (Silva and Cícero, 2014), ensuring the establishment of adequate populations in the field.

The physiological potential of a seed lot is officially evaluated for commercialization through the germination test. However, it evaluates only seed viability, providing information regarding the maximum percentage of germination (Leite et al., 2019). Therefore, the need for complementary information provided by the germination test and the possibility of using high-precision computational resources to evaluate the physiological potential is essential to the quality control programs of seed-producing companies (Medeiros et al., 2020).

In this sense, the automated seed vigor analysis is an alternative, favoring standardization, precision, and objectivity and reducing the time necessary for evaluating the physiological potential of seed lots (Marcos-Filho et al., 2009).

The Automated Seed Vigor Analysis System (Vigor-S) was initially developed to evaluate the physiological potential of corn and soybean seeds, seeking to improve the analysis accuracy and reduce the time required for evaluation (Castan et al., 2018 ). This system evaluates seed quality through the analysis of growth and uniformity of the seedlings generated from them. Thus, a vigor index with values ranging from 0 to 1000 is generated. These parameters are assigned according to the seedling performance, which is directly related to the seed lot quality (Sako et al., 2001).

Studies that evaluate the effectiveness of Vigor-S for determining the physiological potential of seeds are still incipient, as verified in the literature by the studies carried out by Castan et al. (2018) with corn and Medeiros et al. (2019) with common bean. In this sense, this study aimed to verify the effectiveness of the Vigor-S system in the evaluation of the physiological potential of melon seeds.

\section{MATERIAL AND METHODS}

The experiment was conducted in the first half of 2019 at the Laboratory of Seed Analysis of the Universidade Federal Rural do Semi-Árido (UFERSA), Mossoró, RN, Brazil, and at the Laboratories of Seed and Image Analyses of the Escola Superior de Agricultura Luiz de Queiroz (ESALQ), Piracicaba, SP, Brazil. Eight lots of melon seeds (four lots of the hybrid Supreme and four of the hybrid Premier) from the 2018 agricultural year were used. The seeds were packed in kraft paper bags and remained stored in a cold chamber $\left(10^{\circ} \mathrm{C}\right.$ and $\left.50 \% \mathrm{RH}\right)$ during the experimental period. Then, the seeds of each lot were initially subjected to evaluations of water content and physiological potential, as described below.

Water content $(W C)$ : conducted by the oven method at $105 \pm 3^{\circ} \mathrm{C}$ for 24 hours, using two subsamples of approximately twenty seeds for each lot, with results expressed as a percentage, wet basis (Brasil, 2009).

Germination $(G)$ and first germination count $(F C)$ : five replications of fifty seeds per lot were sown between three sheets of paper towels (Germitest ${ }^{\circ}$ ) moistened initially with 2.0 times their dry mass and placed to germinate at $25^{\circ} \mathrm{C}$ in a Biochemical Oxygen Demand (BOD) incubator. The evaluations were carried out at four and eight days after sowing, with normal seedling count (Brasil, 2009), with results expressed as a percentage.

Seedling root length $(R L)$ : the root length of ten normal seedlings taken at random per replication was measured using a ruler graduated in millimeters after counting the germination, with results expressed as $\mathrm{cm} / \mathrm{seedling}$.

Seedling emergence $(E)$ : conducted in a greenhouse $\left(26 \pm 6^{\circ} \mathrm{C}\right)$ with five replications of fifty seeds per lot sown in 200-cell polystyrene trays filled with a commercial substrate (Plantmax ${ }^{\circ}$ ) for cucurbits, with daily irrigation. Seedling emergence was evaluated at twelve days after sowing by counting the emerged normal seedlings, with results expressed as a percentage of normal seedlings for each lot. 
Electrical conductivity $(E C)$ : conducted with five subsamples of fifty seeds for each lot initially weighed on a precision analytical balance $(0.0001 \mathrm{~g})$, left to soak in plastic cups with $75 \mathrm{~mL}$ of distilled water, and maintained in a BOD at $25^{\circ} \mathrm{C}$ for eight hours. Electrical conductivity readings were performed on a Digimed DM-31 conductivity meter, with the mean values expressed in $\mu \mathrm{S} . \mathrm{cm}^{-1}$. $\mathrm{g}^{-1}$ seed (Torres and Marcos-Filho, 2005).

Potassium leaching (KL): five subsamples with 25 seeds per lot were weighed on a precision analytical balance $(0.0001 \mathrm{~g})$ and left to soak in plastic cups containing $50 \mathrm{~mL}$ of distilled water. The cups were maintained in a BOD incubator for two hours at a temperature of $30^{\circ} \mathrm{C}$. The amount of leached potassium was determined using a Digimed DM-62 flame photometer, with the mean values expressed in $\mu \mathrm{g} . \mathrm{K}_{\mathrm{g}} \mathrm{g}^{-1}$ seed, that is, ppm of potassium (Torres and Marcos-Filho, 2005).

Controlled deterioration (CD): the water content of the seeds was initially adjusted to $24 \%$ by the wet atmosphere method (Medeiros et al., 2014). This procedure was carried out in transparent plastic boxes $(11 \times 11 \times 3 \mathrm{~cm})$ with approximately 500 seeds, distributed in a uniform layer on a wire mesh suspended inside and $40 \mathrm{~mL}$ of water. The boxes were covered and maintained in a BOD incubator at $20^{\circ} \mathrm{C}$ until the moisture content of the seeds reached $24 \%$, being monitored through successive weighings (Torres and Marcos-Filho, 2005). Subsequently, the samples were placed in aluminized hermetically sealed containers, remaining for five days in a cold chamber $\left(\approx 10^{\circ} \mathrm{C}\right)$ to achieve hygroscopic balance. After this period, the seeds were placed in a water bath at $45{ }^{\circ} \mathrm{C}$ for 24 hours. Then, these containers were quickly immersed in water at ambient temperature to reduce the temperature, after which the degree of moisture of the seeds was determined and the germination test was setup (Torres et al., 2012). The test evaluation was carried out on the fourth day after sowing, with results expressed as the mean percentage of normal seedlings for each lot.

Accelerated aging with saturated $\mathrm{NaCl}$ solution (AAS): transparent plastic boxes $(11 \times 11 \times 3 \mathrm{~cm})$ were used to form a compartment where $40 \mathrm{~mL}$ of saturated $\mathrm{NaCl}$ solution, obtained using $40 \mathrm{~g} \mathrm{NaCl} 100 \mathrm{~mL}^{-1}$ water, was added to the bottom of each box to provide an environment with $76 \%$ relative humidity inside the plastic boxes (Radke et al., 2016). Each lot was represented by a subsample of approximately 500 seeds arranged on the surface of a wire mesh suspended on the saline solution inside each box to form a uniform layer of seeds on the mesh. The boxes were closed and maintained in a BOD incubator at $41 \pm 0.3{ }^{\circ} \mathrm{C}$ for 72 hours (Marcos-Filho et al., 2006). Subsequently, the seeds were removed from the plastic boxes and subjected to the germination test, following the methodology described for the germination test, with the normal seedling count at four days after sowing. The water content of the seeds was determined when they were removed from the plastic boxes to verify the uniformity of the test conditions.

Seedling image analysis (Vigor-S): image analysis consisted of two distinct tests. Seedlings from the tests of germination and accelerated aging with saturated $\mathrm{NaCl}$ solution were analyzed as described below:

Image analysis of seedlings from the germination test: five replications of twenty seeds of each lot were placed to germinate in two rows on the upper third of the surface of paper towels (Germitest ${ }^{\circ}$ ) moistened with water equivalent to 2.0 times the paper weight. The test was conducted in a germinator at $25 \pm 1{ }^{\circ} \mathrm{C}$ for three days. Then, the seedlings of each replication were transferred from the paper towel to a blue EVA (ethylene-vinyl acetate) sheet arranged on the inner platform of a metal box $(60 \times 50 \times 12 \mathrm{~cm})$, which contained an HP Scanjet 200 scanner mounted inverted inside (Castan et al., 2018).

The images were captured with a 300-dpi resolution, which is mandatory for analysis in the Vigor-S system, being stored on the hard disk and then analyzed by the software Vigor-S. The root of each seedling was marked in red, while the hypocotyl was marked in blue (Figure 1). Manual corrections were performed for errors in the marking of the seedling structures, using the key numbers 1 (hypocotyl correction) and 2 (root correction) and a computer mouse.

The growth index considered a value of $10 \%$ for hypocotyl growth and $90 \%$ for root growth. The vigor index, which results from the combination of growth and uniformity indices, considered a value of $70 \%$ for growth and $30 \%$ for uniformity. The settings were defined based on preliminary tests, and the necessary adjustments to perform the analysis were carried out by accessing the Settings tab, located in the initial interface of the software. 


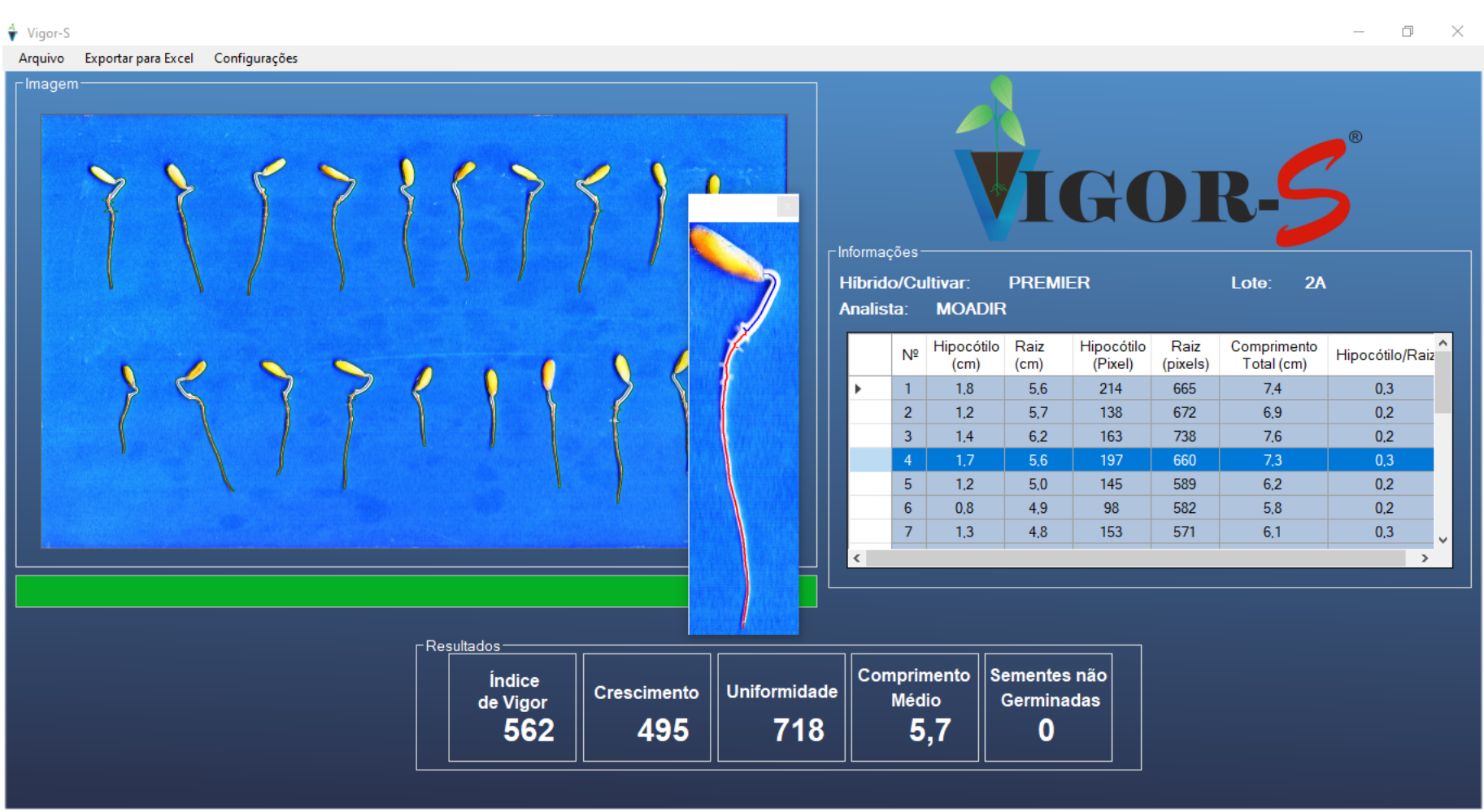

Figure 1. General aspects of the analysis of Cucumis melo L. seedlings by the software Vigor-S, highlighting the hypocotyl (blue color) and root (red color).

The image analysis allowed us to obtain the following variables: hypocotyl length, root length, total seedling length, growth index, development uniformity index, and vigor index. Seedling growth data were obtained in centimeters. The system assigned scores from 0 to 1000 to the seedlings for growth, uniformity, and vigor indices. These scores are directly associated with seed vigor, and the closer the index is to 1000, the higher the seed vigor of the lot.

Image analysis of seedlings from the traditional accelerated aging: the seeds were subjected to the accelerated aging with saturated $\mathrm{NaCl}$ solution before the germination test was setup. The seeds were left to germinate after the aging process, and the seedlings were analyzed by the software Vigor-S, following the same procedures previously described.

The experiment was conducted in a completely randomized design with five replications for each of the tested hybrids. The assumptions of normality of errors and homogeneity of variances were met, according to the ShapiroWilk and Bartlett tests, respectively. The data were subjected to analysis of variance and the means were compared by the Tukey test $(p \leq 0.05)$ using the software SISVAR ${ }^{\circ}$ (Ferreira, 2011). Pearson simple correlation $(p \leq 0.05)$ was also performed between data from traditional tests and vigor indices provided by seedling image analysis (Vigor-S).

\section{RESULTS AND DISCUSSION}

The initial water content of the seeds, as well as after accelerated aging with saturated $\mathrm{NaCl}$ solution and after the period of controlled deterioration, was similar between the hybrids Premier and Supreme, with an increase in seeds submitted to aging and deterioration processes (Table 1).

The uniformity found in the water content of the different seed lots is an important factor for carrying out tests, being essential for the standardization of evaluations and obtaining consistent results, as emphasized by Kikuti and Marcos-Filho (2012).

The germination test showed no significant differences between seed lots for the tested hybrids (Table 2). Similar results were obtained with the first germination count test for the hybrid Premier, which presented no significant 
differences between seed lots. Lot eight of the hybrid Supreme was identified as having the lowest physiological potential.

The germination test provides information on the maximum percentage of germination of a lot, being necessary, for quick decision making, complementary information using vigor tests (Rocha et al., 2015). Thus, the first germination count test was an important tool to complement the information obtained in the germination test, as it evaluates the ability to form normal seedlings in a short time, a characteristic related to seed vigor.

The root length test showed that lots one and four of the hybrid Premier were inferior to the others, although the latter did not differ statistically from lots two and three. The hybrid Supreme showed a lower root length for lot eight, indicating that it has inferior quality compared to the other lots of this hybrid.

Primary root length was reported as one of the most sensitive vigor tests for detecting differences between seed lots of different species (Pego et al., 2011). The seed deterioration process of dicots begins in the meristem areas of the embryonic axis, with the radicle being more sensitive than the plumule (Marcos-Filho, 2015).

Table 1. Initial water content (IWC) after accelerated aging with saturated $\mathrm{NaCl}$ solution (WCAAS) and controlled deterioration (WCCD) of melon (Cucumis melo L.) seed lots of the hybrids Premier and Supreme.

\begin{tabular}{|c|c|c|c|c|}
\hline \multirow{2}{*}{ Hybrid } & \multirow{2}{*}{ Lot } & IWC & WCAAS & WCCD \\
\hline & & \multicolumn{3}{|c|}{ - } \\
\hline \multirow{4}{*}{ Premier } & 1 & 7.1 & 9.7 & 24.3 \\
\hline & 2 & 6.8 & 9.3 & 23.6 \\
\hline & 3 & 7.4 & 9.2 & 22.8 \\
\hline & 4 & 6.9 & 9.3 & 23.5 \\
\hline \multirow{4}{*}{ Supreme } & 5 & 6.8 & 9.0 & 23.7 \\
\hline & 6 & 6.6 & 8.8 & 23.1 \\
\hline & 7 & 6.2 & 8.9 & 23.7 \\
\hline & 8 & 6.4 & 8.8 & 23.1 \\
\hline
\end{tabular}

Table 2. Germination $(G)$, first germination count $(F C)$, root length $(R L)$, seedling emergence (E), electrical conductivity $(E C)$, potassium leaching $(K L)$, controlled deterioration $(C D)$, and accelerated aging with saturated $\mathrm{NaCl}$ solution (AAS) of melon (Cucumis melo L.) seed lots of the hybrids Premier and Supreme.

\begin{tabular}{|c|c|c|c|c|c|c|c|c|c|}
\hline \multirow{2}{*}{ Hybrid } & \multirow{2}{*}{ Lot } & G & $\mathrm{FC}$ & \multirow{2}{*}{$\frac{\mathrm{RL}}{(\mathrm{cm})}$} & \multirow{2}{*}{$\frac{E}{(\%)}$} & \multirow{2}{*}{$\begin{array}{c}\mathrm{EC} \\
\left(\mu \mathrm{S} \mathrm{cm}^{-1} \mathrm{~g}^{-1}\right)\end{array}$} & \multirow{2}{*}{$\frac{\mathrm{KL}}{(\mathrm{ppm})}$} & $C D$ & AAS \\
\hline & & ----- & -1--- & & & & & \multicolumn{2}{|c|}{-------(\%)------- } \\
\hline \multirow{4}{*}{ Premier } & 1 & $99 \mathrm{a}$ & $99 \mathrm{a}$ & $7.4 \mathrm{~b}$ & $100 \mathrm{a}$ & 89.6 a & $35.5 \mathrm{a}$ & $90 \mathrm{c}$ & $90 \mathrm{a}$ \\
\hline & 2 & $99 \mathrm{a}$ & $99 \mathrm{a}$ & $10.8 \mathrm{a}$ & 98 a & $89.0 \mathrm{a}$ & $36.6 \mathrm{a}$ & $94 \mathrm{bc}$ & $96 a$ \\
\hline & 3 & $99 \mathrm{a}$ & $99 \mathrm{a}$ & $11.7 \mathrm{a}$ & 99 a & $90.0 \mathrm{a}$ & $37.1 \mathrm{a}$ & $97 a b$ & $95 a$ \\
\hline & 4 & $99 \mathrm{a}$ & $99 \mathrm{a}$ & $9.4 a b$ & $100 \mathrm{a}$ & $90.2 \mathrm{a}$ & 38.7 a & $98 \mathrm{a}$ & $94 \mathrm{a}$ \\
\hline CV (\%) & - & 1.6 & 1.8 & 15.5 & 1.4 & 5.8 & 8.5 & 2.3 & 3.9 \\
\hline \multirow{4}{*}{ Supreme } & 5 & $98 \mathrm{a}$ & $98 \mathrm{a}$ & $10.2 \mathrm{a}$ & $98 a$ & $81.9 \mathrm{a}$ & $34.3 \mathrm{a}$ & $95 \mathrm{a}$ & $95 \mathrm{a}$ \\
\hline & 6 & $98 \mathrm{a}$ & $98 \mathrm{a}$ & $9.1 \mathrm{a}$ & $98 \mathrm{a}$ & $81.3 \mathrm{a}$ & $34.5 \mathrm{a}$ & 93 a & $94 a b$ \\
\hline & 7 & $99 \mathrm{a}$ & $99 \mathrm{a}$ & $10.8 \mathrm{a}$ & $97 a$ & $78.8 \mathrm{a}$ & $37.1 \mathrm{a}$ & $96 a$ & $94 a b$ \\
\hline & 8 & $96 a$ & $94 \mathrm{~b}$ & $7.0 \mathrm{~b}$ & $93 \mathrm{~b}$ & $112.5 b$ & $44.2 \mathrm{~b}$ & $71 b$ & $89 \mathrm{~b}$ \\
\hline CV (\%) & - & 1.3 & 2.0 & 10.0 & 1.8 & 2.5 & 4.3 & 2.9 & 3.3 \\
\hline
\end{tabular}

*Means followed by the same letter in the column do not differ from each other by the Tukey test $(p \leq 0.05)$. 
The emergence test presented no significant differences for lots of the hybrid Premier. On the other hand, the hybrid Supreme showed a lower percentage of seedling emergence for lot eight, which had less physiological potential compared to the others of the same hybrid.

Vigor tests based on seedling performance are related to the fact that the most vigorous seeds originate more developed seedlings, translating the efficiency of the action of repair mechanisms, the mobilization of reserves, and the synthesis of new tissues during germination (Henning et al., 2010).

The electrical conductivity test showed no significant differences for lots of the hybrid Premier. However, lot eight of the hybrid Supreme had an inferior performance than the others. Similar results were also verified by the potassium leaching test, in which higher leaching rates of this ion were identified for lot eight of the hybrid Supreme, thus indicating it as having a lower physiological potential than the others.

Higher values of electrical conductivity are related to a reduction in membrane integrity, directly compromising seedling development, as less vigorous seeds have poorly structured membranes and damaged cells, which is associated with the deterioration process (Oliveira et al., 2015). Likewise, lots with higher physiological potential have less potassium leaching (Alves and Sá, 2010).

The controlled deterioration test evidenced an inferior performance of lot one of the hybrid Premier, although it did not differ statistically from lot two. This information, associated with that obtained in the root length test, where lot one presented a behavior inferior to the others, allows us to suppose that this lot is in the initial stage of the deterioration process, which was not verified by the other tests.

The result of the controlled deterioration test for the hybrid Supreme followed the trend of the first count, root length, emergence, electrical conductivity, and potassium leaching tests, in which lot eight stood out as being of inferior quality to the others.

Controlled deterioration is a vigor test that uses the same principle as the accelerated aging test but performed under a higher control of temperature and humidity during the aging period. Thus, seeds are exposed to more uniform deterioration conditions, resulting in higher precision and efficiency in distinguishing the physiological potential of seed lots (Zucareli et al., 2011).

The AAS test did not detect differences in vigor between lots of the hybrid Premier. Also, the AAS test of the hybrid Supreme was efficient in stratifying lots at different vigor levels, with lot five showing the highest vigor and not differing from lots six and seven, which, in turn, did not differ from lot eight, which presented the lowest vigor.

The accelerated aging test is considered one of the most sensitive and efficient for evaluating vigor, being included in seed quality control programs (Marcos-Filho, 2015). This test consists of increasing the deterioration rate of seeds due to their exposure to high temperature and relative humidity, environmental factors with higher influence on the intensity and speed of deterioration (Souza et al., 2017). Thus, it allows obtaining information regarding the storage potential of lots, although Marcos-Filho (2015) pointed out that artificial aging can cause changes different from those observed in the natural deterioration process.

The analysis of seedling images (Vigor-S) after the germination test showed no significant differences between lots of the hybrid Premier for most of the variables measured by the software, with the statistical difference between lots only for the uniformity index, which indicated lot one as of superior quality (Table 3). These results are in line with those obtained for most of the traditional vigor tests, which did not show differences between the vigor of the Premier lots, except for the root length and controlled deterioration tests, which indicated lot one as of inferior quality.

The uniformity index has great importance in the analysis of seed vigor, as a rapid and uniform emergence represents an adequate stand of seedlings in the field (Abud et al., 2017). However, this index should not be analyzed in isolation to generate information regarding seed vigor because lots composed only of poorly developed seedlings can also generate a high uniformity index. 
Table 3. Vigor (VI), growth (GI), and uniformity indices (UI) and hypocotyl, root, and total length of melon (Cucumis melo L.) seedlings of the hybrids Premier and Supreme from the germination test and analyzed through image analysis (Vigor-S).

\begin{tabular}{|c|c|c|c|c|c|c|c|}
\hline \multirow{2}{*}{ Hybrid } & \multirow{2}{*}{ Lot } & \multirow{2}{*}{ VI } & \multirow{2}{*}{ GI } & \multirow{2}{*}{ UI } & Hypocotyl & Root & Total \\
\hline & & & & & \multicolumn{3}{|c|}{--------------'(cm)--------------- } \\
\hline \multirow{4}{*}{ Premier } & 1 & $594.2 \mathrm{a}$ & $487.2 \mathrm{a}$ & $843.7 \mathrm{a}$ & $1.0 \mathrm{a}$ & $4.5 \mathrm{a}$ & $5.5 \mathrm{a}$ \\
\hline & 2 & $565.8 \mathrm{a}$ & $474.6 \mathrm{a}$ & $778.5 a b$ & $1.0 \mathrm{a}$ & $4.3 \mathrm{a}$ & $5.3 \mathrm{a}$ \\
\hline & 3 & $568.6 \mathrm{a}$ & $482.7 \mathrm{a}$ & $769.0 \mathrm{~b}$ & $1.0 \mathrm{a}$ & $4.4 \mathrm{a}$ & $5.4 \mathrm{a}$ \\
\hline & 4 & $560.4 \mathrm{a}$ & $471.8 \mathrm{a}$ & $767.2 \mathrm{~b}$ & $1.0 \mathrm{a}$ & $4.3 \mathrm{~b}$ & $5.3 \mathrm{a}$ \\
\hline CV (\%) & - & 3.8 & 4.9 & 4.6 & 8.6 & 5.3 & 4.7 \\
\hline \multirow{4}{*}{ Supreme } & 5 & $629.7 \mathrm{a}$ & $541.1 \mathrm{a}$ & $836.4 \mathrm{a}$ & $1.1 \mathrm{a}$ & $5.0 \mathrm{a}$ & $6.1 \mathrm{a}$ \\
\hline & 6 & $552.0 \mathrm{~b}$ & $452.8 \mathrm{~b}$ & $783.6 \mathrm{~b}$ & $1.0 \mathrm{ab}$ & $4.2 \mathrm{~b}$ & $5.2 \mathrm{~b}$ \\
\hline & 7 & $560.1 \mathrm{ab}$ & $461.1 \mathrm{~b}$ & $791.2 \mathrm{~b}$ & $0.9 \mathrm{~b}$ & $4.2 \mathrm{~b}$ & $5.1 b$ \\
\hline & 8 & $541.8 b$ & $444.7 b$ & $768.4 \mathrm{~b}$ & $1.0 \mathrm{ab}$ & $4.1 b$ & $5.1 \mathrm{~b}$ \\
\hline CV (\%) & - & 7.2 & 8.2 & 7.2 & 10.8 & 8.4 & 8.0 \\
\hline
\end{tabular}

*Means followed by the same letter in the column do not differ from each other by the Tukey test $(p \leq 0.05)$.

The vigor index for the hybrid Supreme obtained through image analysis after the traditional germination test pointed out lots five and seven as more vigorous, although the latter did not differ statistically from six and eight, which were classified as the lowest vigor. Lot five stood out as the most vigorous for growth and uniformity indices, as well as root length and total seedlings.

Taking into account the vigor index, which brings together all the other data acquired by the software in a single index, the results are partially in line with those verified in most of the performed vigor tests, as this index identified lot eight as inferior, a fact also verified by traditional vigor tests, but classified lot six as similar to it, which was verified only in the accelerated aging test with saturated $\mathrm{NaCl}$ solution.

The evaluation of seedling performance after the germination test is not always sufficient to identify differences in vigor between seed lots, especially when they are narrow, as observed in this research. Therefore, the software Vigor-S was used to determine the vigor of lots after the tests of accelerated aging with saturated $\mathrm{NaCl}$ solution.

The vigor index generated from the analysis of seedling images from the accelerated aging test with saturated $\mathrm{NaCl}$ solution showed significant differences between lots of the two tested hybrids (Table 4). Lot one stood out as inferior to the others for the hybrid Premier, a fact confirmed by the vigor and growth indices and seedling performance variables. On the other hand, vigor, growth, and uniformity indices had similar results for the hybrid Supreme, indicating lot eight as less vigorous.

Similar results for the hybrid Premier were obtained by the root length and controlled deterioration tests, which indicated lot one as the least vigorous. Therefore, the analysis of seedling images associated with the accelerated aging test with saturated $\mathrm{NaCl}$ solution identified differences not manifested in the accelerated aging test in saturated $\mathrm{NaCl}$ solution, whose normal seedling count at four days after the test was setup did not identify differences between lots.

Possibly, lot one of the hybrid Premier was in an initial deterioration process because it was pointed out as inferior by the root length and controlled deterioration tests and the vigor and growth indices, in addition to the length of hypocotyl, root, and total of seedlings generated by image analysis of the accelerated aging test with saturated $\mathrm{NaCl}$ solution. Thus, image analysis could be used associated with this test to identify lots with higher storage potential.

The first characteristics affected after the seed aging process are the germination rate and seedling growth, with the loss of the ability to germinate a secondary event (Marcos-Filho, 2015). Thus, the evaluation of seedling growth, for example, can generate more reliable results in terms of seed quality. 
Table 4. Vigor (VI), growth (GI), and uniformity indices (UI) and hypocotyl, root, and total length of melon (Cucumis melo L.) seedlings of the hybrids Premier and Supreme from the accelerated aging test in saturated $\mathrm{NaCl}$ solution and analyzed using image analysis (Vigor-S).

\begin{tabular}{|c|c|c|c|c|c|c|c|}
\hline \multirow{2}{*}{ Hybrid } & \multirow{2}{*}{ Lot } & \multirow{2}{*}{ VI } & \multirow{2}{*}{$\mathrm{Gl}$} & \multirow{2}{*}{ UI } & Hypocotyl & Root & Total \\
\hline & & & & & \multicolumn{3}{|c|}{-------------(cm)------------ } \\
\hline \multirow{4}{*}{ Premier } & 1 & $379.0 \mathrm{~b}$ & $283.1 \mathrm{~b}$ & $602.7 \mathrm{a}$ & $0.6 \mathrm{~b}$ & $2.6 \mathrm{~b}$ & $3.2 \mathrm{~b}$ \\
\hline & 2 & $468.2 \mathrm{a}$ & $371.2 \mathrm{a}$ & $694.4 \mathrm{a}$ & $0.9 \mathrm{a}$ & $3.4 \mathrm{a}$ & $4.3 \mathrm{a}$ \\
\hline & 3 & $457.9 \mathrm{a}$ & $357.6 \mathrm{ab}$ & $691.8 \mathrm{a}$ & $0.7 a b$ & $3.3 a b$ & $4.0 \mathrm{ab}$ \\
\hline & 4 & $471.6 \mathrm{a}$ & $378.4 \mathrm{a}$ & $688.9 \mathrm{a}$ & $1.0 \mathrm{a}$ & $3.5 \mathrm{a}$ & $4.5 \mathrm{a}$ \\
\hline CV (\%) & - & 9.8 & 13.5 & 8.5 & 19.3 & 13.4 & 13.9 \\
\hline \multirow{4}{*}{ Supreme } & 5 & $548.0 \mathrm{a}$ & $470.8 \mathrm{a}$ & $728.3 \mathrm{a}$ & $1.1 \mathrm{a}$ & $4.3 \mathrm{a}$ & $5.4 \mathrm{a}$ \\
\hline & 6 & $550.6 \mathrm{a}$ & $460.9 \mathrm{a}$ & 759.9 a & $1.0 \mathrm{a}$ & $4.2 \mathrm{a}$ & $5.2 \mathrm{a}$ \\
\hline & 7 & $515.1 \mathrm{a}$ & 421.8 a & $732.9 \mathrm{a}$ & $0.9 \mathrm{a}$ & $3.8 \mathrm{a}$ & $4.7 \mathrm{ab}$ \\
\hline & 8 & $406.9 \mathrm{~b}$ & $328.9 \mathrm{~b}$ & $589.0 \mathrm{~b}$ & $0.8 a$ & $3.0 \mathrm{~b}$ & $3.8 \mathrm{~b}$ \\
\hline CV (\%) & - & 10.2 & 10.6 & 11.4 & 14.6 & 10.8 & 10.6 \\
\hline
\end{tabular}

*Means followed by the same letter in the column do not differ from each other by the Tukey test $(p \leq 0.05)$.

Thus, image analysis with the software Vigor-S emerges as an important tool to complement the information obtained with the accelerated aging test with saturated $\mathrm{NaCl}$ solution, as it allows a more accurate vigor evaluation relative to the normal seedling count, which conventionally is carried out to evaluate the test, in addition to reducing the period required for evaluation by one day.

The results of the image analysis for the hybrid Supreme confirm the information from the physiological, biochemical, and resistance tests, as most of them indicated lot eight as of inferior quality compared to the others of the same hybrid.

In addition to being a system that allows easy data interpretation by the seed analyst, Vigor-S allows greater use of the results obtained from the same evaluation, automatically providing the acquisition of information regarding the aerial part and root system separately for each seedling, without the need to interfere with the analysis performed by the system. In addition, the results of the image analysis with the respective values of seedling vigor, uniformity, and length indices can be exported in Excel extensions and PDF, allowing the better organization of the obtained information (Castan et al., 2018).

Thus, the precision presented by the system, the possibility of obtaining specific information for each seedling part (aerial part, root system, and total length), the lowest time needed for analysis, and the reduced cost of the Vigor-S system are factors essential for insertion in seed quality control laboratories (Castan et al., 2018), in addition to reducing the analyst interference in the final result.

The results of the Pearson correlation between the vigor index from the image analysis of the germination test (VI$\mathrm{G}$ ) and the traditional tests for the hybrid Premier showed no significant correlation between them (Table 5). However, these results must be considered coherent, as traditional tests showed no significant differences between lots, a fact also verified by the image analysis of the germination test (VI-G).

The correlation between accelerated aging with saturated $\mathrm{NaCl}$ solution (VI-AAS) and traditional tests showed a significant correlation between image analysis and root length and AAS tests, indicating the similarity of these tests regarding the quality of the seed lots of the hybrid Premier.

Pearson correlation between the vigor index from the image analysis of the germination test (VI-G) and traditional tests for the hybrid Supreme showed no significant results due to the divergences found between the lot classification by the image analysis and traditional tests. 
Table 5. Pearson correlation coefficients between the vigor index from the image analysis (Vigor-S) of the tests of germination (VI-G) and accelerated aging with saturated $\mathrm{NaCl}$ solution (VI-AAS) and the tests of germination $(G)$, first germination count $(F C)$, root length $(R L)$, seedling emergence $(E)$, electrical conductivity $(E C)$, potassium leaching $(\mathrm{KL})$, controlled deterioration $(\mathrm{CD})$, and accelerated aging with saturated $\mathrm{NaCl}$ solution (AAS) of melon (Cucumis melo L.) seed lots of the hybrids Premier and Supreme.

\begin{tabular}{ccccc}
\hline \multirow{2}{*}{ Test } & \multicolumn{2}{c}{ Premier } & IV-G & VI-AAS \\
\cline { 2 - 5 } & VI-G & VI-AAS & $0.04 \mathrm{~ns}$ & $0.47^{*}$ \\
G & $0.06 \mathrm{~ns}$ & $-0.04 \mathrm{~ns}$ & $0.01 \mathrm{~ns}$ & $0.70^{* *}$ \\
FC & $0.04 \mathrm{~ns}$ & $-0.10 \mathrm{~ns}$ & $0.34 \mathrm{~ns}$ & $0.63^{* *}$ \\
RL & $-0.33 \mathrm{~ns}$ & $0.45^{*}$ & $0.27 \mathrm{~ns}$ & $0.68^{* *}$ \\
E & $0.30 \mathrm{~ns}$ & $-0.40 \mathrm{~ns}$ & $-0.33 \mathrm{~ns}$ & $-0.72^{* *}$ \\
EC & $0.21 \mathrm{~ns}$ & $-0.15 \mathrm{~ns}$ & $-0.40 \mathrm{~ns}$ & $-0.70^{* *}$ \\
KL & $-0.08 \mathrm{~ns}$ & $-0.01 \mathrm{~ns}$ & $0.31 \mathrm{~ns}$ & $0.73^{* *}$ \\
CD & $-0.40 \mathrm{~ns}$ & $0.19 \mathrm{~ns}$ & $0.26 \mathrm{~ns}$ & $0.40 \mathrm{~ns}$ \\
AAS & $-0.01 \mathrm{~ns}$ & $0.51^{*}$ &
\end{tabular}

$n$ s, $^{*}$, and $* *$ : not significant, significant at $5 \%$ probability $(p \leq 0.05)$, and significant at $1 \%$ probability $(p \leq 0.01)$, respectively.

The results obtained through the Pearson correlation between the vigor index from the image analysis of the accelerated aging test with saturated $\mathrm{NaCl}$ solution (VI-AAS) and the traditional tests for the hybrid Supreme demonstrated the efficiency of using image analysis applied in association with AAS. A positive and significant correlation was observed between the image analysis (VI-AAS) and the tests of germination, first germination count, root length, emergence, controlled deterioration, and accelerated aging with saturated $\mathrm{NaCl}$ solution. Moreover, a negative and significant correlation was also found between image analysis (VI-AAS) and electrical conductivity and potassium leaching tests.

The positive correlation between the data means that the ranking of lots performed by the image analysis (VI-AAS) was similar to that performed by the traditional tests, while the negative correlation means that the lots with the highest means in the image analysis were those with the lowest means in the electrical conductivity and potassium leaching tests, characterizing high-vigor seeds.

Thus, the high correlation found between traditional tests and image analysis (VI-AAS) confirms the efficiency of the latter in assessing the physiological potential of melon seeds of the hybrid Supreme, and its use is a viable, fast and, easy to perform alternative.

\section{CONCLUSIONS}

The Automated Seed Vigor Analysis System (Vigor-S) is efficient in evaluating the physiological potential of melon seeds, especially when used associated with accelerated aging in saturated $\mathrm{NaCl}$ solution.

\section{REFERENCES}

ABUD, H.F.; CICERO, S.M.; GOMES-JUNIOR, F.G. Computerized image analysis of seedlings to evaluate broccoli seed vigor. Journal of Seed Science, v.39, n.3, p.303-310, 2017. https://doi.org/10.1590/2317-1545v39n3174582

ALVES, M.E.; SÁ, M.E. Avaliação do vigor de sementes de rúcula pelo teste de lixiviação de potássio. Revista Brasileira de Sementes, v.32, n.2, p.108-116, 2010. https://doi.org/10.1590/S0101-31222010000200013 
BARROS, V.S.; SANTOS, T.L.; SILVA, E.O.; SOUSA, J.A.; FIGUEIRÊDO, M.C.B. Agronomic and environmental performance of melon produced in the brazilian semiarid region. Revista Caatinga, v.32, n.4, p.877-888, 2019. http://dx.doi.org/10.1590/198321252019v32n403rc

BESSA, M.A.D.; OLIVEIRA, E.N.A.; FEITOSA, B.F.; FEITOSA, R.M.; ALMEIDA, F.L.C.; OLIVEIRA-NETO, J.O. Bebida alcoólica fermentada de melão (Cucumis melo L.): processamento e caracterização. Brazilian Journal of Food Technology, v.21, n.1, p.1-5, 2018. https:// doi.org/10.1590/1981-6723.21717

BRASIL. Ministério da Agricultura, Pecuária e Abastecimento. Regras para análise de sementes. Ministério da Agricultura, Pecuária e Abastecimento. Secretaria de Defesa Agropecuária. Brasília: MAPA/ACS, 2009. 395p. http:// www.agricultura.gov.br/arq_editor/ file/2946_regras_analise_sementes.pdf

CASTAN, D.O.C.; GOMES-JUNIOR, F.G.; MARCOS-FILHO, J. Vigor-S, a new system for evaluating the physiological potential of maize seeds. Scientia Agricola, v.75, n.2, p.167-172, 2018. http://dx.doi.org/10.1590/1678-992x-2016-0401

DEUS, J.A.L.;SOARES, I.; NEVES, J.C.L.; MEDEIROS, J.F.; MIRANDA, F.R. Fertilizer recommendation system for melon based on nutritional balance. Revista Brasileira de Ciência do Solo, v.39, n.2, p.498-511, 2015. https://doi.org/10.1590/01000683rbcs20140172

FERREIRA, D.F. Sisvar: a computer statistical analysis system. Ciência e Agrotecnologia, v.35, n.6, p.1039-1042, 2011. https://doi. org/10.1590/S1413-70542011000600001

HENNING, F.A.; MERTZ, L.M.; JACOB-JUNIOR, E.A.; MACHADO, R.D.; FISS, G.; ZIMMER, P.D. Composição química e mobilização de reservas em sementes de soja de alto e baixo vigor. Bragantia, v.69, n.3, p.727-734, 2010. https://doi.org/10.1590/S000687052010000300026

KIKUTI, A.L.P.; MARCOS-FILHO, J. Testes de vigor em sementes de alface. Horticultura Brasileira, v.30, n.1, p.44-50, 2012. http:// www.scielo.br/pdf/hb/v30n1/v30n1a08

LEITE, M.S.; LEITE, T.S.; TORRES, S.B.; LEAL, C.C.P.; FREITAS, R.M.O. Classificação do vigor de sementes de maxixe por meio da atividade respiratória. Revista Ciência Agronômica, v.50, n.2, p.307-311, 2019. https://doi.org/10.5935/1806-6690.20190036

MARCOS-FILHO J.; BENNETT, M.A.; MCDONALD, M.B.; EVANS, A.F.; GRASSBAUGH, E.M. Assessment of melon seed vigour by an automated computer imaging system compared to traditional procedures. Seed Science and Technology, v.34, n.2, p.485-497, 2006. https://doi.org/10.15258/sst.2006.34.2.23

MARCOS-FILHO, J. Fisiologia de sementes de plantas cultivadas. Londrina: ABRATES, 2015. 660p.

MARCOS-FILHO, J.; KIKUTI, A.L.; LIMA, L.B. Métodos para avaliação do vigor de sementes de soja, incluindo a análise computadorizada de imagens. Revista Brasileira de Sementes, v.31, n.1, p.102-112, 2009. http://dx.doi.org/10.1590/S0101-31222009000100012

MEDEIROS, A.D.; MARTINS, M.S.; SILVA, L.J.; PEREIRA, M.D.; LEÓN, M.J.Z.; DIAS, D.C.F.S. X-ray imaging and digital processing application in non-destructive assessing of melon seed quality. Journal of Seed Science, v.42, n.1, p.1-13, 2020. https://doi. org/10.1590/2317-1545v42229761

MEDEIROS, A.D.; SILVA, L.J.; CAPOBIANGO, N.P.; FIALHO, C.A.; DIAS, D.C.F.S. Assessing the physiological quality of common bean seeds using the Vigor-S $S^{\circ}$ system and its relation to the accelerated aging test. Journal of Seed Science, v.41, n.2, p.187-195, 2019. https://doi.org/10.1590/2317-1545v41n2211401

MEDEIROS, L.S.; FERREIRA, P.V.; CARVALHO, I.D.E.; OLIVEIRA, F.S.; SILVA, J. Primeiro ciclo de seleção massal na população PM3 de melão (Cucumis melo L.). Revista Verde de Agroecologia e Desenvolvimento Sustentável, v.10, n.4, p.21-27, 2015. https://doi. org/10.18378/rvads.v10i4.3473

MEDEIROS, M.A.; TORRES, S.B.; NEGREIROS, M.Z.; MADALENA, J.A.S. Testes de estresse térmico em sementes de melão. Revista Brasileira de Ciências Agrárias, v.9, n.1, p.7-13, 2014. DOI:10.5039/agraria.v9i1a2393

OLIVEIRA, L.M.; CAVALHEIRO, V.B.D.; MORAES, D.M.; TILMANN, M.A.A.; SCHUCH, L.O.B. Medição do CO 2 como método alternativo para a diferenciação do vigor de lotes de sementes de melancia. Ciência Rural, v.45, n.4, p.606-611, 2015. https://doi. org/10.1590/0103-8478cr20130594

PEGO, R.G.; NUNES, U.R.; MASSAD, M.D. Qualidade fisiológica de sementes e desempenho de plantas de rúcula no campo. Ciência Rural, v.41, n.8, p.1341-1346, 2011. https://doi.org/10.1590/S0103-84782011000800008 
RADKE, A.K.; REIS, B.B.; GEWEHR, E.;ALMEIDA, A.S.; TUNES, L.M.; VILLELA, F.A. Alternativas metodológicas do teste de envelhecimento acelerado em sementes de coentro. Ciência Rural, v.46, n.1, p.95-99. 2016. https://doi.org/10.1590/0103-8478cr20140188

ROCHA, C.R.M.; SILVA, V.N.; CICERO, S.M. Avaliação do vigor de sementes de girassol por meio de análise de imagens de plântulas. Ciência Rural, v.45, n.6, p.970-976, 2015. http://dx.doi.org/10.1590/0103-8478cr20131455

SAKO, Y.; McDONALD, M.B.; FUJIMURA, K.; EVANS, A.J.; BENNETT, M.A. A system for automated seed vigour assessment. Seed Science and Technology, v.29, n.3, p.625-636, 2001. https://www.eurofinsus.com/media/162083/seed-vigor-imaging-system.pdf

SILVA, V.N.; CICERO, S.M. Análise de imagens de plântulas para avaliação do potencial fisiológico de sementes de berinjela. Horticultura Brasileira, v.32, n.2, p.145-151, 2014. http://dx.doi.org/10.1590/S0102-05362014000200004

SOUZA, F.F.J.; SPEHAR, C.R.; SOUZA, N.O.S.; FAGIOLI, M.; SOUZA, R.T.G.; BORGES, S.R. Accelerated ageing test for the evaluation of quinoa seed vigour. Seed Science and Technology, v.45, n.1, p.212-221, 2017. https://doi.org/10.15258/sst.2017.45.1.18

TORRES, S.B.; DANTAS, A.H.; PEREIRA, M.F.S.; BENEDITO, C.P.; SILVA, F.H.A. Deterioração controlada em sementes de coentro. Revista Brasileira de Sementes, v.34, n.2, p.319-326, 2012. https://www.scielo.br/pdf/rbs/v34n2/18.pdf

TORRES, S.B.; MARCOS-FILHO, J. Physiological potential evaluation in melon seeds. Seed Science and Technology, v.33, n.2, p.341350, 2005. https://doi.org/10.15258/sst.2005.33.2.07

ZUCARELI, C.; CAVARIANI, C.; SBRUSSI, C.A.G.; NAKAGAWA, J. Teste de deterioração controlada na avaliação do vigor de sementes de milho. Revista Brasileira de Sementes, v.33, n.4, p.732-742, 2011. https://doi.org/10.1590/S0101-31222011000400015 use, distribution, and reproduction in any medium, provided the original work is properly cited. 